Ege Journal of Medicine / Ege Tıp Dergisi 2021; 60 (2): 113-120

\title{
High-sensitivity cardiac troponin I and D-dimer are risk factors for in-hospital mortality of adult patients with COVID-19: A retrospective cohort study
}

COVID-19 tanılı yetişkinlerde yüksek duyarlıklı kardiyak troponin I ve D-dimer

hastane içi mortalite için risk faktörleridir: Retrospektif kohort çalışması

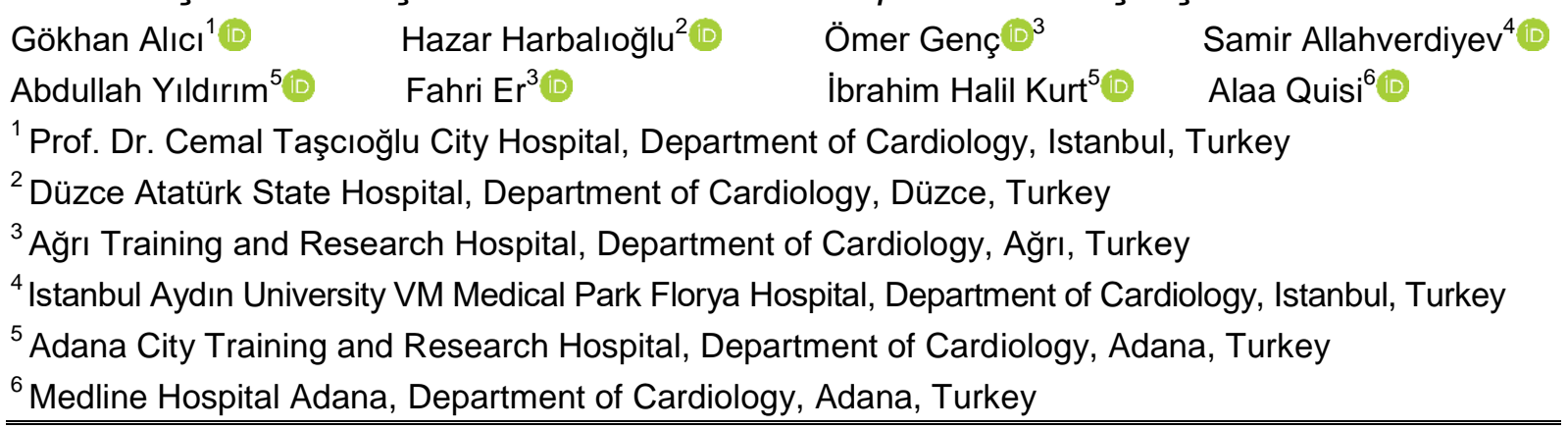

\section{ABSTRACT}

Aim: This study aimed to evaluate the impact of high-sensitivity cardiac troponin I (Hs-cTnl) and Ddimer on in-hospital mortality of adult patients with Coronavirus disease 2019 (COVID-19).

Materials and Methods: The COVID-19 outbreak, a global health disaster, has resulted in significant morbidity and mortality around the world since it emerged in December 2019. The outbreak has gradually spread nationwide. COVID-19 is associated with hemostatic abnormalities and cardiac injury. This retrospective cohort study included a total of 221 adult inpatients. The diagnosis of COVID19 was made according to the World Health Organization's interim guideline and confirmed by RNA detection of SARS-CoV-2. Participants were divided into 2 groups, survivors and non-survivors.

Results: Hs-cTnl and D-dimer levels on admission were significantly higher in non-survivors COVID19 patients $(p<0.05$ for each). Forward stepwise logistic regression analysis demonstrated that age (OR=1.140, 95\% Cl: 1.045-1.244, $p=0.003)$, baseline hs-cTnl level (OR=1.022, 95\% Cl: 1.004-1.041, $p=0.018)$, and baseline $D$-dimer level $(O R=1.790,95 \% \mathrm{Cl}: 1.078-2.972, p=0.024)$ were independent predictors of in-hospital mortality of adult patients with COVID-19. The receiver operating characteristic curve analysis provided a cut-off value of $>18.6 \mathrm{ng} / \mathrm{L}$ for hs-cTnl to predict in-hospital mortality of adult patients with COVID-19 with $100 \%$ sensitivity and $74 \%$ specificity, and a cut-off value of $>1.41 \mathrm{mg} / \mathrm{L}$ for D-dimer with $93.3 \%$ sensitivity and $71.5 \%$ specificity.

Conclusion: High-sensitivity cardiac troponin I and D-dimer levels on admission predict in-hospital mortality of adult patients with COVID-19.

Keywords: SARS-CoV-2, cardiac troponin I, D-dimer, COVID-19, mortality.

\section{ÖZ}

Amaç: Bu çalışmada, yüksek duyarlıklı kardiyak troponin I (Hs-cTnl) ve D-dimerin, Koronavirus hastalığı 2019 (COVID-19) olan yetişkin hastaların hastane içi mortalite üzerine etkisinin değerlendirilmesi amaçlamıştır. 
Gereç ve Yöntem: Küresel bir sağlık felaketi olan COVID-19 salgını, Aralık 2019'da ortaya çıktığından bu yana dünya çapında önemli morbidite ve mortaliteyle sonuçlanarak yavaş yavaş ülke çapında yayıldı. COVID-19 hemostatik anormallikler ve kardiyak hasar ile ilişkilidir. Bu retrospektif kohort çalışmasına toplam 221 yetişkin hasta dahil edilmiştir. COVID-19 tanısı, Dünya Sağlık Örgütü'nün geçici rehberlerine göre konuldu ve SARS-CoV-2' nin RNA tespiti ile doğrulandı. Hastalar sağ kalanlar ve sağ kalımı olmayanlar olarak 2 grupta incelendi.

Bulgular: Başvuru esnasındaki hs-cTnl ve d-dimer düzeyleri sağ kalımı olmayan CoVID-19 hastalarında anlamlı olarak daha yüksekti (her biri için $p<0.005)$. Lojistik regresyon analizinde; yaş (OR=1.140, \%95 Cl: 1.045-1.244, $p=0.003)$, bazal hs-cTnl (OR=1.022, \%95 Cl: 1.004-1.041, $p=0.018)$ ve bazal d-dimer (OR=1.790, \%95 Cl: 1.078-2.972, $p=0.024)$ düzeyleri COVID-19 hastalarında hastane-içi mortalitenin bağımsız prediktörleri olarak tespit edildi. Hastane-içi mortaliteyi öngörmede hs-cTnl için \%100 duyarlılık ve \%74 özgüllükle $18.6 \mathrm{ng} / \mathrm{L}$ kestirim değeri tespit edilirken; $d$-dimer için \%93,3 duyarlılık ve \%71,5 özgüllükle 1,41 mg/L kestirim değeri saptandı.

Sonuç: Başvuru sırasındaki hs-cTnl ve d-dimer düzeyleri COVID-19 tanısı alan yetişkin hastalarda hastane-içi mortaliteyi öngörmektedir.

Anahtar Sözcükler: SARS-CoV-2, kardiyak troponin I, D-dimer, COVID-19, mortalite.

\section{INTRODUCTION}

Coronavirus disease 2019 (COVID-19) is an infectious disease caused by severe acute respiratory syndrome coronavirus 2 (SARS-CoV$2)^{1}$, which was first reported in December $2019^{1}$ and has turned into a COVID-19 pandemic, spreading rapidly worldwide. At present, new confirmed cases and deaths caused by COVID19 still have increased day-by-day around the world. Therefore, the World Health Organization has officially declared a public emergency of international concern. Risk stratification in such pandemics is extremely essential. Thus, in patients with COVID-19, timely and effective predictors of clinical outcomes are immediately needed for risk stratification.

Although SARS-CoV-2 mainly causes pneumonia, acute respiratory distress syndrome (2), cardiac injury (3-7), venous thromboembolism, and arterial thrombosis (8) were reported as complications of COVID-19. In approximately $90 \%$ of inpatients with pneumonia, coagulation activity increases markedly with increasing D-dimer concentrations (9). In addition, the association of coronary artery disease with acute cardiac events and poor outcomes was reported for patients with influenza and other respiratory viral infections (10-12). It has been reported that COVID-19 was associated with cardiac injury and hemostatic abnormalities, and that significantly elevated Ddimer and high-sensitivity cardiac troponin I (hscTnl) levels were associated with poor outcome $(13,14)$. The present study aimed to assess the impact of hs-cTnl and D-dimer on mortality of adult inpatients with COVID-19.

\section{MATERIALS and METHODS}

\section{Study Population and Design}

This retrospective cohort study included a total of hospitalized 221 adult patients. The diagnosis of COVID-19 was made according to the World Health Organization's temporary guideline and was confirmed by RNA detection of SARS-CoV2. Hospitalization was planned according to the following criteria determined by the Republic of Turkey Ministry of Health;

»Mild-moderate pneumonia with respiratory rate $\geq 24$ and $\mathrm{SpO} 2 \leq 93 \%$

»Mild-moderate pneumonia (blood lymphocyte count $<800 / \mu$ or serum CRP $>10 \times$ Upper limit of normal value or ferritin $>500 \mathrm{ng} / \mathrm{ml}$ or D-dimer $>1000 \mathrm{ng} / \mathrm{ml}$, etc.)

"Severe pneumonia (changes in consciousness, respiratory distress, respiratory minutes $\geq 30$, SpO2 $90 \%$ in room air, bilateral diffuse (> 50\%) involvement in lung imaging)

"Hypotension $(<90 / 60 \mathrm{mmHg}$, mean blood pressure $<65 \mathrm{mmHg}$ ), tachycardia $(>100)$

"Sepsis, septic shock,

»Myocarditis, acute coronary syndrome, arrhythmia, and

"Acute kidney injury

All participants diagnosed with COVID-19 were screened, and those who died or were discharged between March 10, 2019, and May10, 2020, were enrolled in the present study. Patients were divided into 2 groups, survivors and nonsurvivors. The study was conducted following the Declaration of Helsinki and was approved by Çukurova University Medical Faculty Ethics 
Committee (99/2020). The need for written informed consent was waived due to the retrospective nature of the study.

\section{Data Collection}

Demographic, epidemiological, laboratory, clinical, treatment, and outcome data were obtained from an electronic medical record system, utilizing admission numbers that were unique to each patient. All data were checked by three physicians (GA, $A Q$, and $H H$ ) and a fourth researcher (AQ) adjudicated any difference in interpretation between the three primary reviewers. Mortality outcomes were followed up to May20, 2020.

\section{Laboratory Procedures}

RNA detection of SARS-CoV-2 in respiratory specimens was carried out by real-time PCR methods. The criteria for discharge were the absence of fever for at least 3 days, substantial improvement in both lungs in chest computed tomography, clinical remission of respiratory symptoms, and one throat-swab sample negative for SARS-CoV-2 RNA. Blood examinations were complete blood count, serum biochemical tests, D-dimer, and myocardial enzymes. Chest radiographs and computed tomography scans were done for all participants.

\section{STATISTICAL ANALYSIS}

Data analyses were performed using SPSS version 22.0 statistical software package (SPSS Inc., Chicago, IL, USA) and MedCalc statistical software v19.5.6 (Ostend, Belgium). Assessment of distribution was carried out using an analytical (Kolmogorov-Smirnov test) method and visual methods (histograms and probability plots). Continuous variables were expressed as mean \pm standard deviation or median (minimummaximum). Categorical variables were expressed as number (percentage). The independent samples t-test or Mann-Whitney U-test was used to compare continuous variables, as appropriate. The Chi-square test or Fisher's exact test was used to compare categorical variables. All significant parameters with a $p$ value of $<0,1$ in the univariate analysis were included in the multivariable model and a forward stepwise logistic regression analysis was used to determine the independent predictors of inhospital mortality of adult patients with COVID19. The odds ratio and $95 \%$ confidence interval of each independent variable were calculated. A receiver operating characteristic (ROC) curve analysis was carried out to identify the optimal cut-off level of D-dimer and hs-cTnl for predicting in-hospital mortality. The area under the curve (AUC) comparison of these predictors was performed using the DeLong method. Youden index method was utilized to establish values of independent predictors. A two-tailed $p$-value of less than 0.05 was considered significant.

\section{RESULTS}

A total of 221 hospitalized COVID-19 patients were enrolled in this retrospective cohort study for the final analysis. 53 patients died during hospitalization and 168 were discharged.

The mean age of the 221 patients was $60.4 \pm$ 15.5 and $40.7 \%$ of the patients were male. Comorbidities were present in almost half of the patients, with hypertension being the most common comorbidity, followed by diabetes mellitus and coronary artery disease. The most common symptom of admission was fever, followed by cough, dyspnea, and fatigue. Leukocyte count, glucose, C-reactive protein, lactate dehydrogenase, hs-cTnl, and D-dimer levels on admission were significantly higher in non-survivors COVID-19 patients. The Comparison of demographic, clinical, laboratory, radiographic, and treatment characteristics of COVID-19 patients according to in-hospital mortality is shown in Table-1.

Forward stepwise logistic regression analysis was carried out to determine the independent predictors of in-hospital mortality. The analysis demonstrated that age $(\mathrm{OR}=1.140,95 \% \mathrm{Cl}$ : 1.045-1.244, $p=0.003$ ), baseline hs-cTnl level (OR=1.022, $95 \% \mathrm{Cl}: 1.004-1.041, \mathrm{p}=0.018)$, and baseline D-dimer level (OR=1.790, $95 \% \mathrm{Cl}$ : 1.078-2.972, $\quad \mathrm{p}=0.024)$ were independent predictors of in-hospital mortality of adult patients with COVID-19 (Table-2).

The ROC curve analysis provided a cut-off value of $>18.6 \mathrm{ng} / \mathrm{L}$ for hs-cTnl to predict in-hospital mortality of COVID-19 patients with $100 \%$ sensitivity and $74.04 \%$ specificity, with the area under the curve being $0.919(95 \% \mathrm{Cl}: 0.872$ $0.965, \mathrm{p}<0.001)$. Also, a cut-off value of $>1.41$ $\mathrm{mg} / \mathrm{L}$ for D-dimer to predict in-hospital with 93.33 $\%$ sensitivity and $71.54 \%$ specificity, with the area under the curve being $0.878(95 \% \mathrm{Cl}$ : $0.828-0.927, p<0.001$ ) was obtained. In the results of pairwise comparisons of the ROC curves, there was no significant difference $(p=0.108)$ (Figure-1a-1b). 
Table-1. Comparison of demographic, clinical, laboratory, radiographic and treatment characteristics of COVID-19 patients according to in-hospital mortality.

\begin{tabular}{|c|c|c|c|c|}
\hline Variable & Total $(n=221)$ & Survivor $(n=168)$ & $\begin{array}{l}\text { Non-survivor } \\
(\mathrm{n}=53)\end{array}$ & p-value \\
\hline \multicolumn{5}{|l|}{$\begin{array}{l}\text { Demographic and clinical } \\
\text { characteristics }\end{array}$} \\
\hline Age (year) & $60.4 \pm 15.5$ & $57.6 \pm 15.8$ & $69.3 \pm 10.7$ & $<0.001^{*}$ \\
\hline Gender, (male) n (\%) & $90(40.7)$ & $69(41.1)$ & $21(39.6)$ & 0.852 \\
\hline BMI $\left(\mathrm{kg} / \mathrm{m}^{2}\right)$ & $28.7 \pm 5.0$ & $28.6 \pm 4.9$ & $30.3 \pm 6.8$ & 0.413 \\
\hline Current smoker, n (\%) & $70(31.7)$ & $51(30.4)$ & $19(35.8)$ & 0.454 \\
\hline Durations of hospitalization (day) & $8(1-22)$ & $8(2-17)$ & $7(1-22)$ & 0.656 \\
\hline \multicolumn{5}{|l|}{ Comorbidity } \\
\hline DM, n (\%) & $79(35.7)$ & $59(35.1)$ & $20(37.7)$ & 0.729 \\
\hline HLP, n (\%) & $52(23.5)$ & $36(21.4)$ & $16(30.2)$ & 0.190 \\
\hline $\mathrm{HT}, \mathrm{n}(\%)$ & $102(46.2)$ & $72(42.9)$ & $30(56.6)$ & 0.080 \\
\hline CAD, n (\%) & $54(24.4)$ & $32(19.0)$ & $22(41.5)$ & $0.001^{*}$ \\
\hline $\mathrm{HF}, \mathrm{n}(\%)$ & $20(9.0)$ & $13(7.7)$ & $7(13.2)$ & 0.271 \\
\hline COPD, n (\%) & $21(9.5)$ & $18(10.7)$ & $13(24.5)$ & $0.012^{\star}$ \\
\hline Stroke, n (\%) & $12(5.4)$ & $10(6.0)$ & $2(3.8)$ & 0.735 \\
\hline \multicolumn{5}{|l|}{ Symptom } \\
\hline Fever (temperature $\left.\geq 37,3^{\circ} \mathrm{C}\right), \mathrm{n}(\%)$ & $192(86.9)$ & $145(86.3)$ & $47(88.7)$ & \\
\hline Cough, $\mathrm{n}(\%)$ & $174(78.7)$ & $132(78.6)$ & $42(79.2)$ & \\
\hline Dyspnea, n (\%) & $150(67.9)$ & $111(66.1)$ & $39(73.6)$ & 0.636 \\
\hline Fatigue, n (\%) & $60(27.1)$ & $45(26.8)$ & $15(28.3)$ & \\
\hline Diarrhea, n (\%) & $10(4.5)$ & $8(4.8)$ & $2(3.8)$ & \\
\hline \multicolumn{5}{|l|}{ Laboratory Findings } \\
\hline Hemoglobin $(\mathrm{g} / \mathrm{L})$ & $132(92-178)$ & $135(92-174)$ & $129(99-178)$ & 0.329 \\
\hline Leukocyte count, $\times 10^{3} / \mathrm{uL}$ & $9.1 \pm 6.3$ & $7.4 \pm 3.6$ & $14.4 \pm 9.3$ & $<0.001^{*}$ \\
\hline Platelet count, $\times 10^{3} / \mathrm{uL}$ & $229.5 \pm 105.2$ & $232.0 \pm 98.1$ & $221.5 \pm 125.5$ & 0.539 \\
\hline Glucose (mmol/L) & $8.8 \pm 5.3$ & $7.9 \pm 3.9$ & $11.7 \pm 7.9$ & $<0.001^{*}$ \\
\hline GFR (mL/min per 1.73 m2) & $95.0(70.0-99.0)$ & $95.0(70.0-99.0)$ & $95(87.0-98.0)$ & 0.569 \\
\hline $\mathrm{CRP}(\mathrm{nmol} / \mathrm{L})$ & $1066.7 \pm 876.2$ & $830.5 \pm 764.8$ & $1810.0 \pm 811.5$ & $<0.001^{*}$ \\
\hline $\mathrm{LDH}(\mathrm{nmol} / \mathrm{L})$ & $\begin{array}{l}5216.7 \\
(2100.0-10450.0)\end{array}$ & $\begin{array}{l}5050.0 \\
(2633.3-10266.7)\end{array}$ & $\begin{array}{l}7050.0 \\
(2100.0-10450.0)\end{array}$ & $<0.001^{*}$ \\
\hline Hs-cTnl (ng/L) & $12.0(1.4-236.0)$ & $7.0(1.4-154.0)$ & $77.5(20.0-236.0)$ & $<0.001^{\star}$ \\
\hline D-dimer (mg/L) & $1.29(0.01-9.58)$ & $0.90(0.01-5.24)$ & $3.37(1.12-9.58)$ & $<0.001^{\star}$ \\
\hline \multicolumn{5}{|l|}{ Imaging Features } \\
\hline No features, n (\%) & $6(2.7)$ & $6(3.6)$ & $0(0.0)$ & \multirow{6}{*}{$<0.001^{\star}$} \\
\hline Consolidation, n (\%) & $31(14.0)$ & $29(17.3)$ & $2(3.8)$ & \\
\hline Ground-glass opacity, n (\%) & $86(38.9)$ & $68(40.5)$ & $18(34.0)$ & \\
\hline Infiltration, n (\%) & $23(10.4)$ & $21(12.5)$ & $2(3.8)$ & \\
\hline Pleural effusion, $\mathrm{n}(\%)$ & $21(9.5)$ & $4(2.4)$ & $17(32.1)$ & \\
\hline Mixed features, n (\%) & $54(24.4)$ & $40(23.8)$ & $14(26.4)$ & \\
\hline Lymphadenopathy, n (\%) & $59(26.7)$ & $39(23.2)$ & $20(37.7)$ & $0.049^{*}$ \\
\hline \multicolumn{5}{|l|}{ Treatments } \\
\hline Antibiotic treatment, $\mathrm{n}(\%)$ & 203 (91.9) & $152(90.5)$ & $51(96.2)$ & 1.000 \\
\hline Antiviral treatment, $\mathrm{n}(\%)$ & $218(98.6)$ & $165(98.2)$ & $53(100.0)$ & 1.000 \\
\hline Hydroxychloroquine use, n (\%) & $221(100.0)$ & $168(100.0)$ & $53(100.0)$ & - \\
\hline Invasive mechanical ventilation, $\mathrm{n}(\%)$ & $99(44.8)$ & $48(28.6)$ & $51(96.2)$ & $<0.001^{\star}$ \\
\hline
\end{tabular}

Data are presented as number (\%), mean \pm standard deviation or median (minimum-maximum).

${ }^{*} p$-value was calculated using the Independent Samples t-test or the Mann-Whitney U-test for continuous variables and the ChiSquare test or the Fisher's exact test for categorical variables as appropriate. $p$ value $<0.05$ was considered significant.

BMI: Body mass index, CAD: Coronary artery disease, COPD: Chronic obstructive pulmonary disease, CRP: C-reactive protein, DM: Diabetes mellitus, GFR: Glomerular filtration rate, HF: Heart failure, HLP: Hyperlipidemia, Hs-cTnl: High sensitivity cardiac troponin I, HT: Hypertension, LDH: Lactate dehydrogenase 
Table-2. Risk factors associated with in-hospital mortality in COVID-19 patients.

\begin{tabular}{|c|c|c|c|c|}
\hline \multirow[t]{2}{*}{ Variable } & \multicolumn{2}{|l|}{ Univariate Analysis } & \multicolumn{2}{|l|}{ Multivariate Analysis } \\
\hline & OR (95 \% Cl) & p-value & OR (95 \% Cl) & p-value \\
\hline Age (year) & $1.061(1.034-1.088)$ & $<0.001^{*}$ & $1.140(1.045-1.244)$ & $0.003^{*}$ \\
\hline Oxygen saturation (\%) & $0.946(0.916-0.977)$ & $0.001^{*}$ & - & - \\
\hline HLP, n (\%) & $1.586(0.793-3.170)$ & 0.192 & - & - \\
\hline HT, n (\%) & $1.739(0.933-3.243)$ & 0.082 & - & - \\
\hline CAD, n (\%) & $3.016(1.546-5.885)$ & $0.001^{*}$ & - & - \\
\hline COPD, n (\%) & 2.708 (1.224-5.992) & $0.014^{\star}$ & - & - \\
\hline Leukocyte count, $\times 10^{3} / \mathrm{uL}$ & $1.230(1.145-1.320)$ & $<0.001^{*}$ & - & - \\
\hline Glucose (mg/dL) & $1.007(1.003-1.010)$ & $<0.001^{\star}$ & - & - \\
\hline CRP (mg/L) & $1.013(1.009-1.017)$ & $<0.001^{\star}$ & - & - \\
\hline $\mathrm{LDH}(\mathrm{U} / \mathrm{L})$ & $1.007(1.003-1.010)$ & $<0.001^{*}$ & - & - \\
\hline Hs-cTnl (ng/L) & $1.032(1.020-1.045)$ & $<0.001^{*}$ & $1.022(1.004-1.041)$ & $0.018^{*}$ \\
\hline D-dimer (mg/L) & $2.158(1.680-2.771)$ & $<0.001^{*}$ & $1.790(1.078-2.972)$ & $0.024^{\star}$ \\
\hline
\end{tabular}

${ }^{*} \mathrm{p}$-value $<0.05$ was considered significant.

CAD: Coronary artery disease, $\mathrm{Cl}$ : Confidence interval, COPD: Chronic obstructive pulmonary disease, CRP: C-reactive protein, HLP: Hyperlipidemia, Hs-cTnl: High sensitivity cardiac troponin I, HT: Hypertension, LDH: Lactate dehydrogenase, OR: Odds ratio.

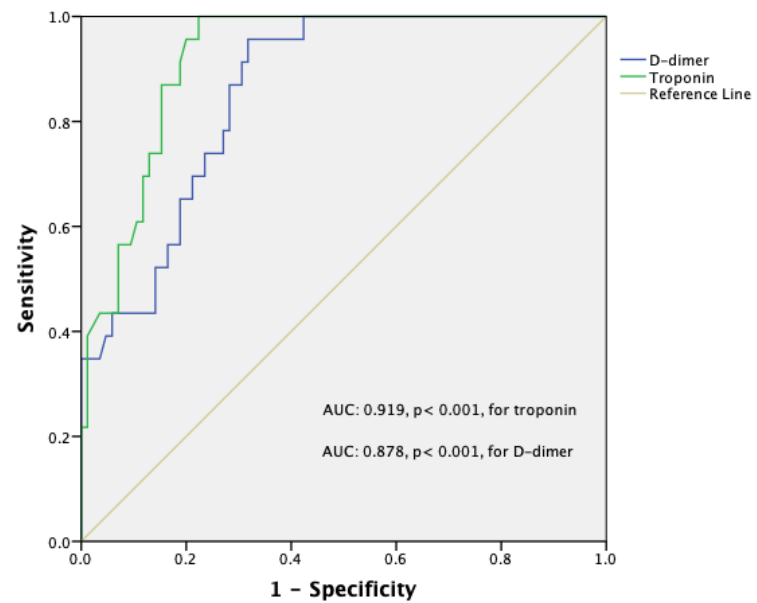

Figure-1a. Receiver operating characteristic (ROC) curve of D-dimer, and troponin for predicting in-hospital mortality (AUC: area under the curve, SE: standard error, $95 \%$ $\mathrm{Cl}$ : 95\% confidence interval) and pairwise comparison of ROC curves.

\begin{tabular}{lrcrc}
\hline Variable & AUC & SE $^{a}$ & $95 \% \mathrm{Cl}^{\mathrm{b}}$ & $\mathrm{p}$ value \\
D-dimer & 0.878 & 0.0253 & 0.828 to & $<0.001$ \\
& & & 0.927 & \\
Hs-cTnl & 0.919 & 0.0238 & 0.872 to & $<0.001$ \\
& & & 0.965 & \\
\hline
\end{tabular}

${ }^{a}$ DeLong et al., 1988. ${ }^{b}$ Binomial exact.

\begin{tabular}{lll}
\hline & D-dimer (mg/dL) & Hs-cTnl (ng/L) \\
\hline Sensitivity, \% & 93.33 & 100 \\
Specificity, \% & 71.54 & 74.04 \\
Youden index & 0.6487 & 0.7404 \\
Cut-off value $^{*}$ & 1.41 & 18.6 \\
\hline
\end{tabular}

* Cut-off values were determined from the Youden index.

Figure-1b. Pairwise comparison of ROC curves.

\begin{tabular}{lr}
\hline D-dimer $\sim$ Hs-cTnl & \\
\hline Difference between areas & 0.0627 \\
Standard Error $^{\text {a }}$ & 0.0390 \\
$95 \%$ Confidence Interval & -0.0138 to 0.139 \\
Z statistic & 1.607 \\
Significance level & $\mathrm{P}=0.1081$ \\
\hline
\end{tabular}

${ }^{a}$ DeLong et al., 1988

\section{DISCUSSION}

This retrospective cohort study described certain risk factors for death in adult hospitalized patients with COVID-19 in Turkey. The major findings of our study identify that older age, hs-cTnl, and Ddimer levels on admission were associated with higher in-hospital mortality. Additionally, cut-off 
values of $18.6 \mathrm{ng} / \mathrm{L}$ for hs-cTnl and $1.41 \mathrm{mg} / \mathrm{L}$ for D-dimer to predict in-hospital mortality of COVID19 patients were well established.

Previously, advanced age has been reported as a significant independent predictor of mortality in viral infections, including severe acute respiratory syndrome (15), middle east respiratory syndrome (16-19), and COVID-19 (14, 20, 21). Our study verified that older age was associated with mortality in patients with COVID-19. The potential underlying pathophysiological mechanism of these findings may refer to altered immune responses in elderly individuals. With aging, changes occur in immunity $(22,23)$. As a result, the aged people are at greater risk of sustaining more severe and more durable infections with increased morbidity and mortality, such as respiratory tract infections (24). Smits et al. (25), investigated macaques inoculated with SARSCoV and revealed that older macaques had stronger host innate responses to virus infection than younger ones, with an increase in differential expression of genes associated with inflammation, while decreased expression of type I interferon beta. Furthermore, the agedependent defects in cellular components of the adaptive immune response and the excess production of type 2 cytokines could lead to a lack of control of viral replication and more prolonged proinflammatory responses, probably causing adverse outcome (26).

Several studies have reported a substantial association between pneumonia and cardiovascular complications $(10,27,28)$. These complications have clinical implications because they can trigger acute cardiorespiratory decompensation and substantially increase risk $(29,30)$. Elevated troponin levels are not only associated with acute respiratory infections and sepsis but could also be used as a marker of disease severity and predicts probable cardiac events (31). Previous studies have demonstrated that up to $30 \%$ of patients with COVID-19 presented elevated cardiac troponin levels reflecting cardiac injury $(2,14,32)$. In contrast to patients with normal values, individuals with elevated troponin were advanced age, had significantly higher proportion of comorbidities, including coronary artery disease, hypertension, and diabetes mellitus (32), and showed higher inhospital mortality $(14,32)$ The present study confirmed that hs-cTnl level on admission was significantly higher in non-survivor COVID-19 patients and were also associated with higher rates of in-hospital mortality. Possible pathophysiology of myocardial damage in
COVID-19 involve microangiopathy, viral myocarditis, unmasked coronary artery disease, and cytokine-related myocardial injury (33). However, so far, it has not been proven whether any of these mechanisms are the main mechanism of troponin elevation and / or heart damage in COVID-19 patients.

Reported to be one of the laboratory findings of hospitalized COVID-19 patients, D-dimer reflects the activation of coagulation and fibrinolysis due to cross-linked fibrin formation and lysis (34). It has been indicated that COVID-19 was correlated with hemostatic abnormalities and, that the association of markedly elevated D-dimer with adverse outcome and mortality $(13,14)$. Guan et al. (35), reported that non-survivor COVID-19 patients had significantly higher Ddimer levels than survivors. Similarly, Tang et al. (13), observed markedly elevated D-dimer levels in fatal cases with COVID-19. Zhou et al. (14), also found that D-dimer on admission was associated with in-hospital death in COVID-19 patients. Recent guideline on the recognition and management of coagulopathy in COVID-19 from the International Thrombosis and Hemostasis Association have defined the markedly increased D-dimer on admission as a 3-4-fold increase (36). In the present study, a D-dimer cut-off value of $1.41 \mathrm{mg} / \mathrm{L}$ was determined to predict in-hospital mortality.

The potential underlying pathophysiological mechanism of hypercoagulable state in patients with COVID-19 may refer to several aspects. An imbalance between pro-inflammatory and antiinflammatory response in viral infections $(37,39)$, hypoxia-related prothrombotic state in critically ill patients (40), age-related hypercoagulability (41, 42) sepsis-induced coagulopathy or even disseminated intravascular coagulation might trigger endothelial cells and stimulate thrombosis (43).

In the present study, the mortality rate was $24 \%$. This rate was higher than that reported in previous studies $(44,45)$. This heterogeneity is probably due to differences in the illness severity of the patients enrolled. $44.8 \%$ of the patients were critically ill, admitted to the intensive care unit, and required invasive mechanical ventilation.

This study has certain limitations. First it might have a selection bias because of its retrospective design. Larger prospective studies are required to validate the impact of hs-cTnl and D-dimer on mortality of patients with COVID-19. Second, data regarding the time between illness onset 
and hospital admission were unobtainable. This might have influenced our findings regarding the link between baseline levels of hs-cTnl and Ddimer and mortality. Third, severity scores were not attainable. Thus, the relationship between these markers and disease severity was not evaluated.

\section{CONCLUSION}

High-sensitivity cardiac troponin I and D-dimer levels on admission are independently associated with in-hospital mortality of adult patients with COVID-19. A cut-off value of 18,6 $\mathrm{ng} / \mathrm{L}$ for hs-cTnl and another of $1,41 \mathrm{mg} / \mathrm{L}$ for $\mathrm{D}$ dimer to predict in-hospital mortality is well established. However, further studies are warranted.

\section{Acknowledgements}

Funding: This research did not receive any specific grant from any funding agency.

Conflict of Interest: The authors declared no conflict of interest.

\section{References}

1. Zhu N, Zhang D, Wang W, et al. A Novel Coronavirus from Patients with Pneumonia in China, 2019. N Engl J Med 2020; 382 (8): 727-33.

2. Huang C, Wang Y, Li X, et al. Clinical features of patients infected with 2019 novel coronavirus in Wuhan, China. Lancet 2020; 395 (10223): 497-506.

3. Hendren NS, Drazner MH, Bozkurt B, Cooper LT, Jr. Description and Proposed Management of the Acute COVID-19 Cardiovascular Syndrome. Circulation2020.

4. Deng Q, Hu B, Zhang Y, et al. Suspected myocardial injury in patients with COVID-19: Evidence from frontline clinical observation in Wuhan, China. Int J Cardiol 2020.

5. Ammirati E, Wang DW. SARS-CoV-2 inflames the heart. The importance of awareness of myocardial injury in COVID-19 patients. Int J Cardiol 2020.

6. Kochi AN, Tagliari AP, Forleo GB, Fassini GM, Tondo C. Cardiac and arrhythmic complications in patients with COVID-19. J Cardiovasc Electrophysiol 2020.

7. Mishra AK, Sahu KK, Lal A, Sargent J. Patterns of heart Injury in COVID - 19 and relation to outcome. J Med Virol 2020.

8. Klok FA, Kruip M, van der Meer NJM, et al. Incidence of thrombotic complications in critically ill ICU patients with COVID-19. Thromb Res 2020.

9. Milbrandt EB, Reade MC, Lee M, et al. Prevalence and significance of coagulation abnormalities in community-acquired pneumonia. Mol Med 2009; 15 (11-12): 438-45.

10. Corrales-Medina VF, Musher DM, Shachkina S, Chirinos JA. Acute pneumonia and the cardiovascular system. Lancet 2013; 381 (9865): 496-505.

11. Udell JA, Zawi R, Bhatt DL, et al. Association between influenza vaccination and cardiovascular outcomes in high-risk patients: a meta-analysis. JAMA 2013; 310 (16):1711-20.

12. Blackburn R, Zhao H, Pebody R, Hayward A, Warren-Gash C. Laboratory-Confirmed Respiratory Infections as Predictors of Hospital Admission for Myocardial Infarction and Stroke: Time-Series Analysis of English Data for 2004-2015. Clin Infect Dis 2018; 67 (1): 8-17.

13. Tang N, Li D, Wang X, Sun Z. Abnormal coagulation parameters are associated with poor prognosis in patients with novel coronavirus pneumonia. J Thromb Haemost 2020; 18 (4):844-47.

14. Zhou F, Yu T, Du R, et al. Clinical course and risk factors for mortality of adult inpatients with COVID-19 in Wuhan, China: a retrospective cohort study. Lancet 2020; 395 (10229):1054-62.

15. Choi KW, Chau TN, Tsang O, et al. Outcomes and prognostic factors in 267 patients with severe acute respiratory syndrome in Hong Kong. Ann Intern Med 2003; 139 (9): 715-23.

16. Choi WS, Kang Cl, Kim Y, et al. Clinical Presentation and Outcomes of Middle East Respiratory Syndrome in the Republic of Korea. Infect Chemother 2016; 48 (2):118-26.

17. Kim SW, Park JW, Jung HD, et al. Risk factors for transmission of Middle East respiratory syndrome coronavirus infection during the 2015 outbreak in South Korea. Clin Infect Dis 2017; 64 (5): 551-57.

18. Sherbini N, Iskandrani A, Kharaba A, Khalid G, Abduljawad M, Al-Jahdali H. Middle East respiratory syndrome coronavirus in Al-Madinah City, Saudi Arabia: Demographic, clinical and survival data. J Epidemiol Glob Health 2017; 7 (1): 29-36. 
19. Park JE, Jung S, Kim A, Park JE. MERS transmission and risk factors: a systematic review. BMC Public Health 2018; 18 (1): 574.

20. Zheng Z, Peng F, Xu B, et al. Risk factors of critical \& mortal COVID-19 cases: A systematic literature review and meta-analysis. J Infect 2020.

21. Du RH, Liang LR, Yang CQ, et al. Predictors of Mortality for Patients with COVID-19 Pneumonia Caused by SARS-CoV-2: A Prospective Cohort Study. Eur Respir J 2020.

22. Licastro F, Candore G, Lio D, et al. Innate immunity and inflammation in ageing: a key for understanding agerelated diseases. Immun Ageing 2005; 2:8.

23. Plackett TP, Boehmer ED, Faunce DE, Kovacs EJ. Aging and innate immune cells. J Leukoc Biol2004; 76 (2): 291-99.

24. Meyer KC. The role of immunity in susceptibility to respiratory infection in the aging lung. Respir Physiol2001; 128 (1):23-31.

25. Smits SL, de Lang A, van den Brand JM, et al. Exacerbated innate host response to SARS-CoV in aged nonhuman primates. PLoS Pathog2010; 6 (2):e1000756.

26. Opal SM, Girard TD, Ely EW. The immunopathogenesis of sepsis in elderly patients. Clin Infect Dis2005; 41 Suppl 7: S504-12.

27. Corrales-Medina VF, Musher DM, Wells GA, Chirinos JA, Chen L, Fine MJ. Cardiac complications in patients with community-acquired pneumonia: incidence, timing, risk factors, and association with short-term mortality. Circulation 2012; 125 (6):773-81.

28. Violi $\mathrm{F}$, Cangemi $\mathrm{R}$, Falcone $\mathrm{M}$, et al. Cardiovascular Complications and Short-term Mortality Risk in Community-Acquired Pneumonia. Clin Infect Dis 2017; 64 (11): 1486-93.

29. Mandal P, Chalmers JD, Choudhury G, Akram AR, Hill AT. Vascular complications are associated with poor outcome in community-acquired pneumonia. QJM 2011; 104 (6): 489-95.

30. Cangemi R, Calvieri C, Falcone M, et al. Relation of Cardiac Complications in the Early Phase of CommunityAcquired Pneumonia to Long-Term Mortality and Cardiovascular Events. Am J Cardiol 2015; 116 (4): 647-51.

31. Frencken JF, van Baal L, Kappen TH, et al. Myocardial Injury in Critically III Patients with Communityacquired Pneumonia. A Cohort Study. Ann Am Thorac Soc 2019; 16 (5): 606-12.

32. Guo T, Fan Y, Chen M, et al. Cardiovascular Implications of Fatal Outcomes of Patients With Coronavirus Disease 2019 (COVID-19). JAMA Cardiol 2020.

33. Tersalvi G, Vicenzi M, Calabretta D, Biasco L, Pedrazzini G, Winterton D. Elevated troponin in patients with Coronavirus Disease 2019 (COVID-19): possible mechanisms. J Card Fail 2020.

34. Zhang L, Long Y, Xiao H, Yang J, Toulon P, Zhang Z. Use of D-dimer in oral anticoagulation therapy. Int $J$ Lab Hematol 2018.

35. Guan WJ, Ni ZY, Hu Y, et al. Clinical Characteristics of Coronavirus Disease 2019 in China. N Engl J Med 2020.

36. Barrett CD, Moore HB, Yaffe MB, Moore EE. ISTH interim guidance on recognition and management of coagulopathy in COVID-19: A Comment. J Thromb Haemost 2020.

37. Liu Q, Zhou YH, Yang ZQ. The cytokine storm of severe influenza and development of immunomodulatory therapy. Cell Mol Immunol 2016; 13 (1): 3-10.

38. Wong JP, Viswanathan S, Wang M, Sun LQ, Clark GC, D'Elia RV. Current and future developments in the treatment of virus-induced hypercytokinemia. Future Med Chem 2017; 9 (2):169-178.

39. Levi M, van der Poll T. Coagulation and sepsis. Thromb Res 2017; 149:38-44.

40. Ninivaggi $M$, de Laat $M$, Lance $M M$, et al. Hypoxia Induces a Prothrombotic State Independently of the Physical Activity. PLoS One 2015; 10 (10): e0141797.

41. Mari D, Mannucci PM, Coppola R, Bottasso B, Bauer KA, Rosenberg RD. Hypercoagulability in centenarians: the paradox of successful aging. Blood 1995; 85 (11): 3144-3149.

42. Mari D, Ogliari G, Castaldi D, Vitale G, Bollini EM, Lio D. Hemostasis and ageing. Immun Ageing 2008; 5: 12.

43. Iba T, Levy JH, Warkentin TE, et al. Diagnosis and management of sepsis-induced coagulopathy and disseminated intravascular coagulation. J Thromb Haemost 2019; 17 (11): 1989-1994.

44. Wang D, Hu B, Hu C, et al. Clinical Characteristics of 138 Hospitalized Patients With 2019 Novel Coronavirus-Infected Pneumonia in Wuhan, China. JAMA 2020.

45. Zhang J, Wang X, Jia X, et al. Risk factors for disease severity, unimprovement, and mortality of COVID-19 patients in Wuhan, China. Clin Microbiol Infect 2020. 